\title{
On the impact of post weld heat treatment on the microstructure and mechanical properties of creep resistant $2.25 \mathrm{Cr}-1 \mathrm{Mo}-0.25 \mathrm{~V}$ weld metal
}

\author{
Hannah Schönmaier ${ }^{1, \star}$ (D), Christian Fleißner-Rieger ${ }^{1}$, Ronny Krein ${ }^{2}$, Martin Schmitz-Niederau ${ }^{2}$, and \\ Ronald Schnitzer ${ }^{1}$ \\ ${ }^{1}$ Department of Materials Science, Montanuniversiät Leoben, Franz-Josef-Straße 18, 8700 Leoben, Austria \\ ${ }^{2}$ Voestalpine Böhler Welding Germany GmbH, Hafenstraße 21, 59067 Hamm, Germany
}

Received: 27 July 2021

Accepted: 11 October 2021

Published online:

3 November 2021

(C) The Author(s) 2021

\begin{abstract}
Creep resistant low-alloyed $2.25 \mathrm{Cr}-1 \mathrm{Mo}-0.25 \mathrm{~V}$ steel is typically applied in hydrogen bearing heavy wall pressure vessels in the chemical and petrochemical industry. For this purpose, the steel is often joined via submerged-arc welding. In order to increase the reactors efficiency via higher operating temperatures and pressures, the industry demands for improved strength and toughness of the steel plates and weldments at elevated temperatures. This study investigates the influence of the post weld heat treatment (PWHT) on the microstructure and mechanical properties of $2.25 \mathrm{Cr}-1 \mathrm{Mo}-0.25 \mathrm{~V}$ multi-layer weld metal aiming to describe the underlying microstructure-property relationships. Apart from tensile, Charpy impact and stress rupture testing, micro-hardness mappings were performed and changes in the dislocation structure as well as alterations of the MX carbonitrides were analysed by means of high resolution methods. A longer PWHT-time was found to decrease the stress rupture time of the weld metal and increase the impact energy at the same time. In addition, a longer duration of PWHT causes a reduction of strength and an increase of the weld metals ductility. Though the overall hardness of the weld metal is decreased with longer duration of PWHT, PWHT-times of more than $12 \mathrm{~h}$ lead to an enhanced temper resistance of the heat-affected zones (HAZs) inbetween the weld beads of the multi-layer weld metal. This is linked to several influencing factors such as reaustenitization and stress relief in the course of multi-layer welding, a higher fraction of larger carbides and a smaller grain size in the HAZs within the multi-layer weld metal.
\end{abstract}

Handling Editor: P. Nash.

Address correspondence to E-mail: hannah.schoenmaier@unileoben.ac.at 


\section{Introduction}

The creep resistant steel $2.25 \mathrm{Cr}-1 \mathrm{Mo}-0.25 \mathrm{~V}$ was introduced as a further development of the conventional alloy $2.25 \mathrm{Cr}-1 \mathrm{Mo}$ in the early 1990s. Compared to its predecessor, the V-modified version possesses several advantages such as increased strength at elevated temperatures, improved resistance to hydrogen attack and temper embrittlement as well as sufficient toughness [1-5]. On account of these benefits, $2.25 \mathrm{Cr}-1 \mathrm{Mo}-0.25 \mathrm{~V}$ is often used for heavy wall pressure vessels for high temperature hydrogen service in power stations as well as in the petroleum and chemical industry, e.g. for hydrocracking reactors $[2,6,7]$. For this purpose, the $2.25 \mathrm{Cr}-1 \mathrm{Mo}-0.25 \mathrm{~V}$ steel plates are usually joined via multi-layer submergedarc welding $(S A W)[6,8]$. For the application in hydrogen bearing reactors, the $2.25 \mathrm{Cr}-1 \mathrm{Mo}-0.25 \mathrm{~V}$ steel and in particular the numerous weld seams have to withstand combinations of high pressures and temperatures of more than $400{ }^{\circ} \mathrm{C}$. Consequently, high temperature strength and toughness are required and have to be maintained over several years [8].

In steels exposed to creep environment, solid solution and precipitation hardening are the only strengthening mechanisms which are able to effectively hinder dislocation movement [9-12]. Therefore, in ferritic and martensitic creep resistant steels, especially the distribution, size and stability of fine precipitates are of utmost importance for well-designed mechanical properties at high temperatures [12-15]. These fine precipitates are usually carbonitrides formed by micro-alloying elements such as $\mathrm{V}$, $\mathrm{Nb}$ and $\mathrm{Ti}$ and consist of a cubic crystal structure of type MX [16-20]. As long as they are small in size and homogeneously distributed within the matrix, they act as obstacles for dislocations. On account of their small size, they cannot be cut or bypassed by dislocations and therefore increase the creep strength by decelerating dislocation creep [10, 11]. However, the fine carbonitrides are only effective as dislocation barriers if they are stable at high temperatures [20-22].

As $2.25 \mathrm{Cr}-1 \mathrm{Mo}-0.25 \mathrm{~V}$ weld metal tends to strongly harden during welding and in general exhibits low as-welded toughness, it is usually subjected to a post weld heat treatment (PWHT) [2, 6, 23-25]. Common PWHT-temperatures are
$705 \pm 14{ }^{\circ} \mathrm{C}$ and the advised minimum PWHT-time is $8 \mathrm{~h}$, as described in API recommended practice 934-A [23]. In general, the PWHT has two main functions which are the softening of the weld metal and the relief of stresses resulting from welding [26, 27]. In addition, the PWHT stabilizes the weld metals microstructure by carbide and carbonitride precipitation and improves its properties for the subsequent application under creep loading conditions $[27,28]$. Notwithstanding that many researchers $[2,4,6,7,29-35]$ have addressed the mechanical properties of low-alloyed $\mathrm{CrMoV}$-steel in various conditions, little attention has been paid on the weld metal and the combined impact of multi-layer welding and PWHT-time on its mechanical properties and the underlying correlation with its sub-microstructure. Furthermore, even though it was described for a $\mathrm{CrMoV}$-alloy with a high Cr-content in the as-welded condition by Liu et al. [36], the inhomogeneous micro-hardness distribution over the multi-layer weld metals cross section and especially its alteration with longer duration of PWHT was not thematised before. However, it has been shown that this inhomogeneous microstructure of the multi-layer weld metal caused by locally different temperature profiles is vitally important for its creep resistance [34-36].

This study aims to comprehensively describe the microstructure-property relationships of $2.25 \mathrm{Cr}-$ $1 \mathrm{Mo}-0.25 \mathrm{~V}$ multi-layer weld metal by analysing and comparing the microstructure and mechanical properties after various times of PWHT. The weld metals tensile properties, impact energy and stress rupture time after various durations of PWHT are correlated with the observed changes of the dislocation structure and nanosized precipitates. With regard to the application in creep environment, particular focus is placed on a balanced ratio of toughness and creep resistance.

In addition, this study intends to explain the alteration of the micro-hardness over the multi-layer weld metals cross section and the local enhancement of temper resistance with increasing PWHT-time for the first time. By discussing influencing factors from multi-layer welding as well as changes in grain size and carbide area fraction, potential causes for the local differences in temper resistance are established. 
Table 1 Chemical composition of the $2.25 \mathrm{Cr}-1 \mathrm{Mo}-0.25$ weld metal in $\mathrm{wt}^{\mathrm{O}} \%$

\begin{tabular}{lllllllll}
\hline Element & $\mathrm{Fe}$ & $\mathrm{Cr}$ & $\mathrm{Mn}$ & $\mathrm{Mo}$ & $\mathrm{V}$ & $\mathrm{C}$ & $\mathrm{Si}$ & $\mathrm{Nb}$ \\
\hline Value & bal & 2.20 & 1.00 & 1.00 & 0.30 & 0.08 & 0.08 & 0.01 \\
\hline
\end{tabular}

\section{Material and methods}

\subsection{Cr-1Mo-0.25V multi-layer weld metal}

The investigated $2.25 \mathrm{Cr}-1 \mathrm{Mo}-0.25 \mathrm{~V}$ all-weld metal specimens were produced by single wire multi-layer SAW. Two $24 \mathrm{~mm}$ thick $2.25 \mathrm{Cr}-1 \mathrm{Mo}-0.25 \mathrm{~V}$ steel plates were joined with a root gap of $22 \mathrm{~mm}$ and a bevel angle of $0^{\circ}$ using a $2.25 \mathrm{Cr}-1$ Mo backing strip. The weld metal consisted of nine layers in total with two weld beads per layer. The backing strip and the diluted area were removed from the weld metal before further investigations were conducted.

Table 1 shows the chemical composition of the $2.25 \mathrm{Cr}-1 \mathrm{Mo}-0.25 \mathrm{~V}$ all-weld metal and Table 2 provides the welding parameters in detail.

\section{Heat treatment}

For the HV1 hardness mappings and the microstructural investigation, the all-weld metal was cut into pieces of approximately $20 \mathrm{~mm}$ thickness. A PWHT at $705{ }^{\circ} \mathrm{C}$ for different times between 0.5 and $100 \mathrm{~h}$ was performed in a laboratory scale Nabertherm N 11/HR box furnace followed by air cooling. Previously to the PWHT, the whole weld seam was subjected to a dehydrogenation treatment at $250{ }^{\circ} \mathrm{C}$ for $10 \mathrm{~h}$ to remove diffusible hydrogen. Specimens which only experienced this dehydrogenation treatment are referred to as-welded.

\section{Overview of experimental conditions}

Table 3 provides an overview of the experimental conditions of the specimens for mechanical testing and microstructural investigation.

\section{Mechanical testing}

Mechanical testing of the $2.25 \mathrm{Cr}-1 \mathrm{Mo}-0.25 \mathrm{~V}$ multilayer weld metal was conducted on samples which were post weld heat treated for $8,16,32$ and $100 \mathrm{~h}$ at $705{ }^{\circ} \mathrm{C}$. From each of the PWHT conditions one tensile testing sample according to DIN EN ISO 5178:2019 [37] and five Charpy V-notch impact testing samples according to DIN EN ISO 148-1:2016 [38] were produced. The tensile testing samples exhibited an initial gauge length of $50 \mathrm{~mm}$ and an inner diameter of $10 \mathrm{~mm}$ and the Charpy V-notch samples exhibited a quadratic cross section of $10 \times 10 \mathrm{~mm}^{2}$ and a total length of $55 \mathrm{~mm}$. The Charpy V-notch specimens were cross weld specimens and the tensile sample were all-weld metal samples taken in welding direction. The V-notch of the Charpy specimens was located in the middle of the weld metals cross section, where the weld beads overlap each other, respectively, as described in DIN EN ISO 9016:2020 [39]. The Charpy impact testing was performed at a temperature of $-30{ }^{\circ} \mathrm{C}$ and the tensile testing was performed at room temperature using a strain rate of $20 \mathrm{MPa} / \mathrm{s}$. Furthermore, uniaxial stress rupture tests of the weld metal heat treated for $8,16,32$ and $100 \mathrm{~h}$ at $705{ }^{\circ} \mathrm{C}$ were carried out at a testing temperature of $540{ }^{\circ} \mathrm{C}$ under an applied constant load of $210 \mathrm{MPa}$ according to the ASME Boiler and Pressure Vessel Code Section VIII Division 2:2019 [40] and ASTM E139-11(2018) [41]. The stress rupture test samples were taken in welding direction from the middle of the weld metals cross section and exhibited a gauge length of $62 \mathrm{~mm}$ and an inner sample diameter of $13 \mathrm{~mm}$. In addition, Vickers hardness mappings with a load of $9.807 \mathrm{~N}$ (HV1) were performed on half of the weld metals cross section, respectively, utilizing

Table 2 Overview of the single-wire SAW parameters

\begin{tabular}{|c|c|c|c|c|c|c|c|}
\hline Polarity & $\begin{array}{l}\text { Welding } \\
\text { position }\end{array}$ & Welding sequence & $\begin{array}{l}\text { Travel } \\
\text { speed }\end{array}$ & $\begin{array}{l}\text { Welding } \\
\text { current }\end{array}$ & $\begin{array}{l}\text { Welding } \\
\text { voltage }\end{array}$ & $\begin{array}{l}\text { Preheat } \\
\text { temperature }\end{array}$ & $\begin{array}{l}\text { Interpass } \\
\text { temperature }\end{array}$ \\
\hline $\begin{array}{l}\text { Alternating } \\
\text { current }\end{array}$ & PA & $\begin{array}{r}\text { left } \leftrightarrow \text { right } \\
\text { alternating }\end{array}$ & $\begin{array}{c}50 \mathrm{~cm} / \\
\min \end{array}$ & $550 \mathrm{~A}$ & $30 \mathrm{~V}$ & $200{ }^{\circ} \mathrm{C}$ & $230{ }^{\circ} \mathrm{C}$ \\
\hline
\end{tabular}


Table 3 Specimen conditions for mechanical testing and microstructural investigation

\begin{tabular}{|c|c|c|c|c|c|c|}
\hline PWHT-time (h) & Hardness mapping & Mechanical testing & SEM & EBSD & STEM & TKD \\
\hline 0 & $\mathrm{x}$ & & & $\mathrm{x}$ & $\mathrm{x}$ & \\
\hline 0.5 & $\mathrm{x}$ & & & & & \\
\hline 2 & $\mathrm{x}$ & & & & & \\
\hline 4 & $\mathrm{x}$ & & & & & \\
\hline 6 & $\mathrm{x}$ & & & & & \\
\hline 8 & $\mathrm{x}$ & $\mathrm{x}$ & $\mathrm{x}$ & & $\mathrm{x}$ & \\
\hline 10 & $\mathrm{x}$ & & & $\mathrm{x}$ & & \\
\hline 12 & $\mathrm{x}$ & & & & & \\
\hline 16 & $\mathrm{x}$ & $\mathrm{x}$ & $\mathrm{x}$ & & $\mathrm{x}$ & \\
\hline 20 & $\mathrm{x}$ & & & & & \\
\hline 24 & $\mathrm{x}$ & & & & & \\
\hline 32 & $\mathrm{x}$ & $\mathrm{x}$ & $\mathrm{x}$ & & $\mathrm{x}$ & \\
\hline 100 & $\mathrm{x}$ & $\mathrm{x}$ & $\mathrm{x}$ & & $\mathrm{x}$ & $\mathrm{x}$ \\
\hline
\end{tabular}

an automatic hardness tester Qness Q $60 \mathrm{~A}+$. The HV1 indents were placed with a measurement grid with a distance of $500 \mu \mathrm{m}$ in horizontal and vertical direction.

\section{Scanning electron microscopy}

Scanning electron microscopic (SEM) images were taken with a FEI Versa 3D DualBeam workstation at two positions within the cross section of the $2.25 \mathrm{Cr}-$ $1 \mathrm{Mo}-0.25 \mathrm{~V}$ weld metal after varying PWHT-times at $705{ }^{\circ} \mathrm{C}$, respectively. More precisely, ten backscattered electron (BSE) SEM images at a magnification of 2500 were taken within the last deposited weld bead and in the heat-affected zone (HAZ) between the last and the subjacent weld bead, see Fig. 1 .

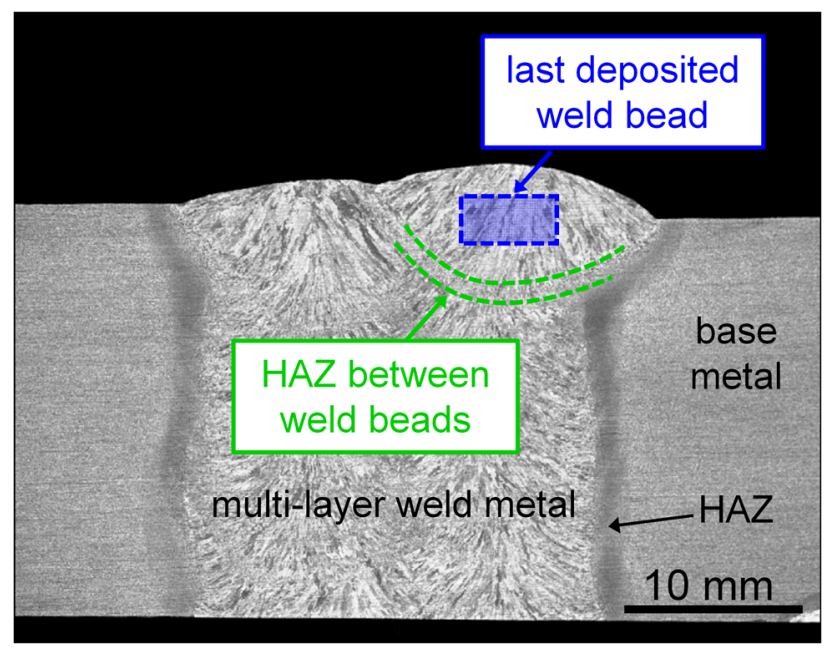

Figure 1 Stereo-microscopic image of the macro-etched cross section of the $2.25 \mathrm{Cr}-1 \mathrm{Mo}-0.25 \mathrm{~V}$ weld metal, displaying the positions where the SEM images were taken.
The evaluation of the carbide fraction, relative to the total investigated area of the weld metal cross section, was conducted with an Olympus Stream Motion image processing software.

Furthermore, scanning transmission electron microscopic (STEM) images were taken on electrolytically prepared transmission electron microscopic (TEM) specimens from the upper layer of the weld metal in the as-welded condition and after a PWHT-time of 8, 16, 32 and $100 \mathrm{~h}$. Therefore, lamellas with a thickness of 150 to $200 \mu \mathrm{m}$ were cut in welding direction followed by mechanical thinning to a thickness of $90 \mu \mathrm{m}$. The lamellas were then cut to discs with a diameter of $3 \mathrm{~mm}$ which were further thinned utilizing a combination of electro- and ionpolishing. The electro-polishing was conducted with an electro polisher TenuPol-5 from Struers utilizing Struers A2-I electrolyte. The polishing temperature was around $-5{ }^{\circ} \mathrm{C}$, the voltage was $34-39 \mathrm{~V}$ and the flow rate was 14 . The final ion polishing step was conducted in a GATAN PIPS II precision ion polishing system at a voltage of $4 \mathrm{keV}$ with a thinning velocity of $2 \mathrm{rpm}$ for approximately $10 \mathrm{~min}$. The electro-polished TEM specimens were investigated in a FEI Versa 3D DualBeam workstation using a FEI STEM detector. The SEM was operated in standard mode and the voltage was set to $30 \mathrm{kV}$.

\section{Electron backscatter diffraction and transmission Kikuchi diffraction}

All electron backscatter diffraction (EBSD) and Transmission Kikuchi diffraction (TKD) measurements were taken on a FEI Versa 3D DualBeam 
workstation equipped with an EDAX Hikari XP EBSD system. EBSD grain size analysis was performed on the specimen in the as-welded condition and the specimen with a PWHT of $10 \mathrm{~h}$ at $705^{\circ} \mathrm{C}$. One EBSD scan was taken in the last deposited weld bead and one in the HAZ between the last and the subjacent weld bead, respectively. The specimen tilt was $70^{\circ}$ and the working distance was between 10 and $15 \mathrm{~mm}$. A voltage of $30 \mathrm{kV}$ was used to map an area of approximately $180 \times 180 \mu \mathrm{m}^{2}$ with a step size of $0.3 \mu \mathrm{m}$ and $6 \times 6$ binning. The EBSD maps were evaluated with OIM 7 data analysis software. A reconstruction of the prior austenite grain structure was performed with the program ARPGE by Cayron [42] using Nishiyama-Wasserman orientation relationship.

TKD measurements were conducted on carbon replicas which were prepared from the weld metals cross section according to the method described by Bhattacharya et al. [43]. A specimen tilt of $0^{\circ}$, a working distance of $10 \mathrm{~mm}$ and a voltage of $30 \mathrm{kV}$ was chosen. For a more detailed description of TKD, the reader is referred to Sneddon et al. [44]. The Kikuchi pattern obtained from the TKD analysis were evaluated using EDAX TEAM software.

\section{Results}

\section{Mechanical properties}

The results from tensile testing are presented in Fig. 2. Both, ductility and strength of the multi-layer

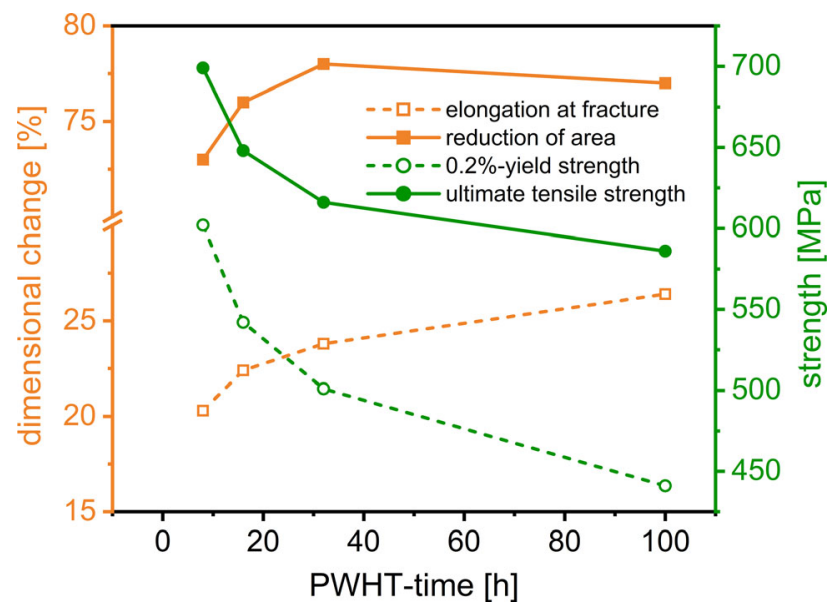

Figure 2 Elongation at fracture and reduction of area and as well as $0.2 \%$-yield strength and ultimate tensile strength as a function of the applied PWHT-time. weld metal significantly depend on the applied PWHT-time. A longer PWHT-time at $705{ }^{\circ} \mathrm{C}$ leads to an increase of the reduction of area and elongation at fracture on the one hand and a decrease of the $0.2 \%$ yield strength and the ultimate tensile strength on the other hand.

Figure 3 displays the influence of the PWHT-time at $705{ }^{\circ} \mathrm{C}$ on the $2.25 \mathrm{Cr}-1 \mathrm{Mo}-0.25 \mathrm{~V}$ weld metals Charpy impact energy and stress rupture time. The stress rupture time is used as estimation for the resistance against creep damage and is presented as normalized value, which is the total value divided by the minimal value of the data set, respectively. For $2.25 \mathrm{Cr}-1 \mathrm{Mo}-0.25 \mathrm{~V}$ multi-layer weld metal, the Charpy impact energy at $-30{ }^{\circ} \mathrm{C}$ and the stress rupture time at $540{ }^{\circ} \mathrm{C}$ behave contrarily. The Charpy impact energy increases with longer PWHT-time whereas the stress rupture time decreases. However, this increase in Charpy impact energy and decrease in stress rupture time is considerably strong for lower PWHT-times up to $32 \mathrm{~h}$. For even longer PWHTtimes up to $100 \mathrm{~h}$, no significant change in impact energy occurs and the decrease in stress rupture time is less pronounced compared to the shorter PWHTtimes.

To assess local differences in hardness over the multi-layer weld metals cross section, HV1 hardness mappings were performed on the specimens post weld heat treated for varying times at $705^{\circ} \mathrm{C}$. Figure 4 shows the mean hardness of the last deposited weld bead and the HAZ between the last and the subjacent weld bead determined from the HV1 hardness mappings, respectively, versus the applied



Figure 3 Charpy impact energy and normalized stress rupture time versus PWHT-time at $705{ }^{\circ} \mathrm{C}$. 
PWHT-time. Additionally, three selected HV1 hardness mappings of the weld metal samples with different PWHT-times are provided for a better visualization of the hardness evolution during the PWHT.

The overall hardness of the weld metal significantly decreases with longer PWHT-times, which is in accordance with the results from tensile testing presented in Fig. 2. However, Fig. 4 clearly shows that for shorter PWHT-times the hardness difference between the last deposited weld bead and the subjacent HAZ is more pronounced than for longer PWHT-times at $705^{\circ} \mathrm{C}$. In the as-welded condition $(0 \mathrm{~h})$ and after short PWHT-times of $0.5,2$ and $4 \mathrm{~h}$, the hardness in the last deposited weld bead is higher than in the subjacent HAZ. After a PWHT-time of 8 and $10 \mathrm{~h}$, the hardness of the weld metals cross section is nearly homogeneous. After these intermediate PWHT-times, no significant differences between the hardness of the HAZs in the multi-layer weld metal and the hardness within the weld beads are visible, see micro-hardness mapping after $10 \mathrm{~h}$ of PWHT. Interestingly, after $12 \mathrm{~h}$ of PWHT, the trend changes and the hardness mappings reveal that the HAZs between the weld beads are now harder than the weld beads itself. This higher hardness of the HAZs becomes more and more pronounced with increasing PWHT-times, see HV1 hardness mapping after $100 \mathrm{~h}$ of PWHT in Fig. 4. As the overall hardness of the multi-layer weld metal decreases with longer PWHTtime, the higher hardness of the HAZs compared to the weld beads is considered to be an enhanced temper resistance of the HAZs. In addition, the overall difference in hardness over the weld metals cross section decreases from 150 HV1 in the as-welded condition to $50 \mathrm{HV} 1$ in the $100 \mathrm{~h}$ post weld heat treated condition.

\section{Carbide fractions and grain size analysis}

To clarify the reasons for the hardness differences over the multi-layer weld metals cross section with longer PWHT-time, carbide area fraction analysis of
Figure 4 Mean HV1 hardness of the last deposited weld bead and the HAZ between the last and the subjacent weld bead versus the PWHT-time. Additionally, HV1 hardness mappings of the weld metals cross section after a PWHT of $0 \mathrm{~h}$ (as-welded condition), $10 \mathrm{~h}$ and $100 \mathrm{~h}$ are presented.

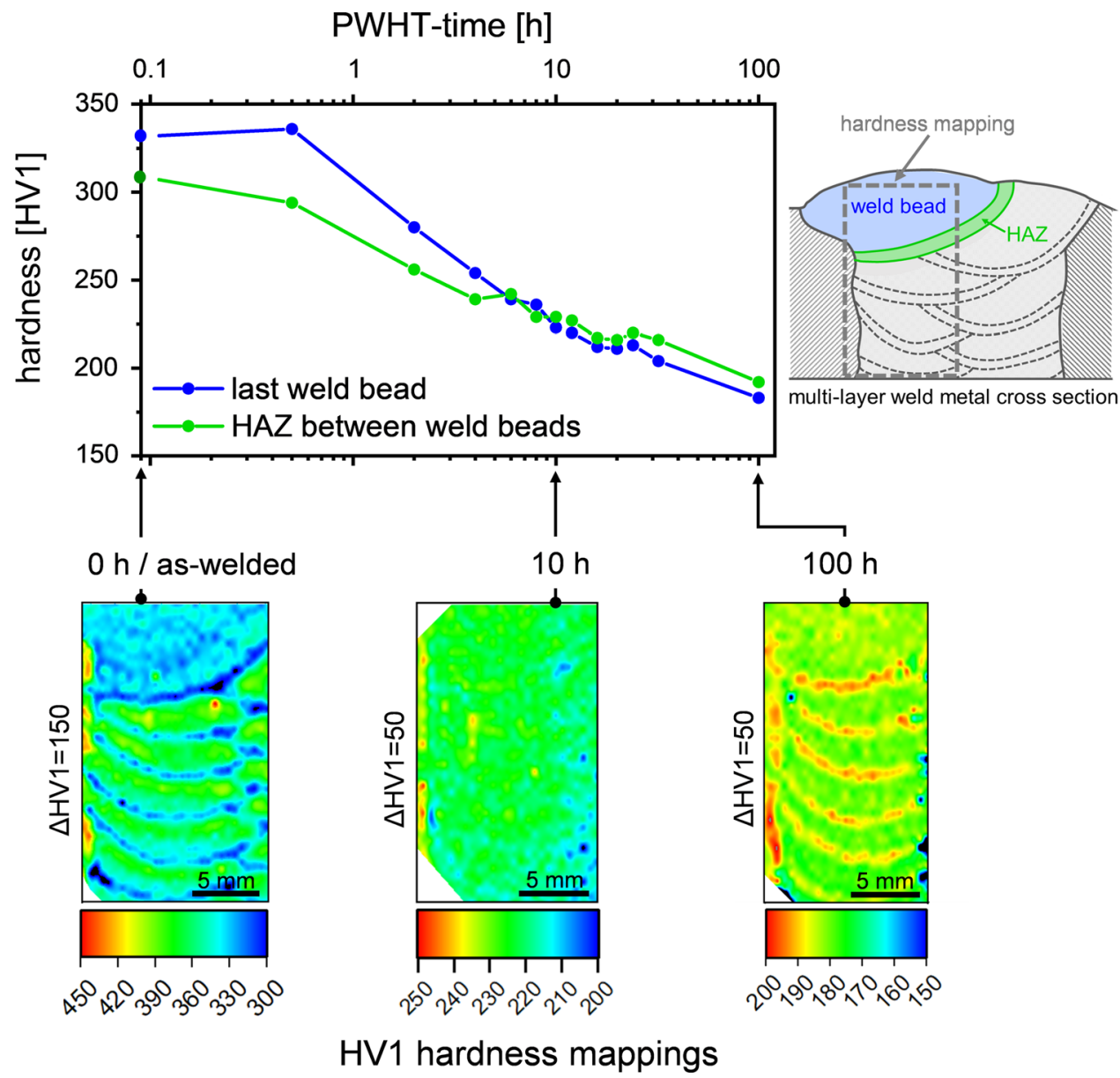


SEM images was performed. Figure 5 a shows a BSE SEM image taken in the last weld bead of the specimen post weld heat treated for $100 \mathrm{~h}$. In BSE mode, the carbides appear lighter and the non-metallic inclusions appear darker than the surrounding bainitic matrix. Figure $5 b$ displays the carbide area fractions in the last deposited weld bead and in the HAZ between the last and the subjacent weld bead after various PWHT-times at $705{ }^{\circ} \mathrm{C}$. In addition, the corresponding HV1 hardness mappings are provided. The carbide area fractions in the last deposited weld bead and in the HAZ between the last and the subjacent weld bead both increase with longer
PWHT-time. Furthermore, with longer duration of PWHT, the difference of the carbide area fractions in the two investigated areas increases. The increase in carbide area fraction with longer PWTH-time is more pronounced for the HAZ between the weld beads than for the last deposited weld bead. However, it has to be noted that with this analysis only carbides which are large enough to be visualized at a magnification of 2500 in the SEM could be taken into account.

Furthermore, EBSD measurements were conducted to assess the influence of multi-layer welding on the bainite and prior austenite grain size. Figure 6a gives (a) SEM BSE image

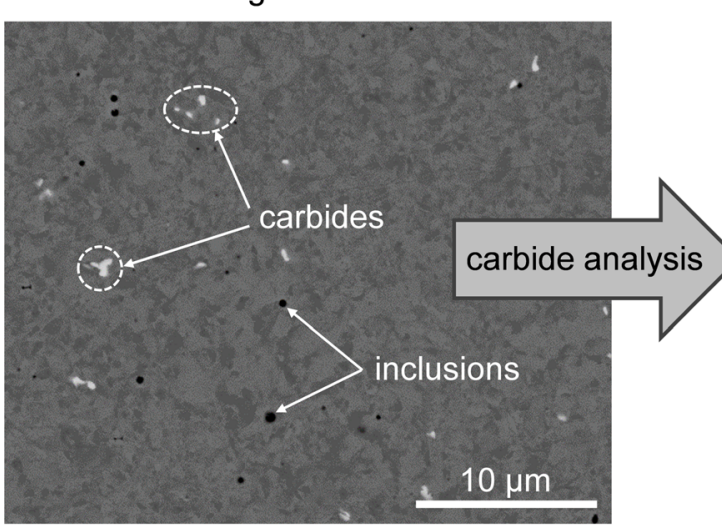

(b)

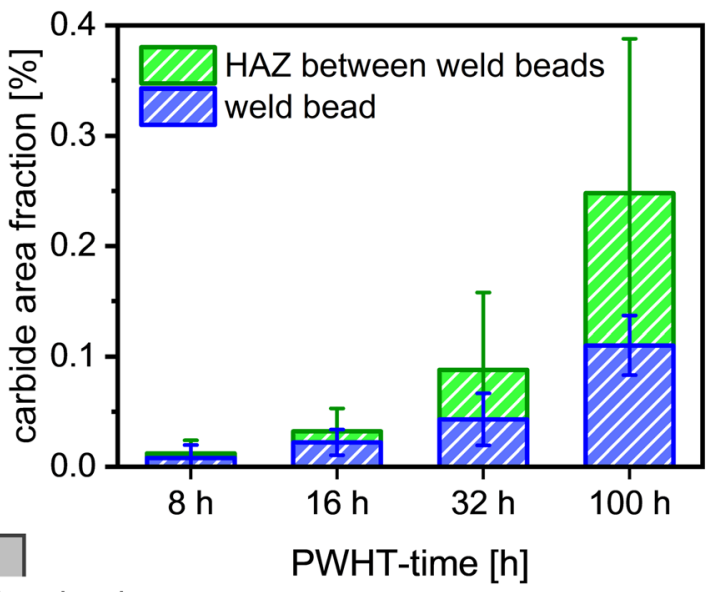

(c)

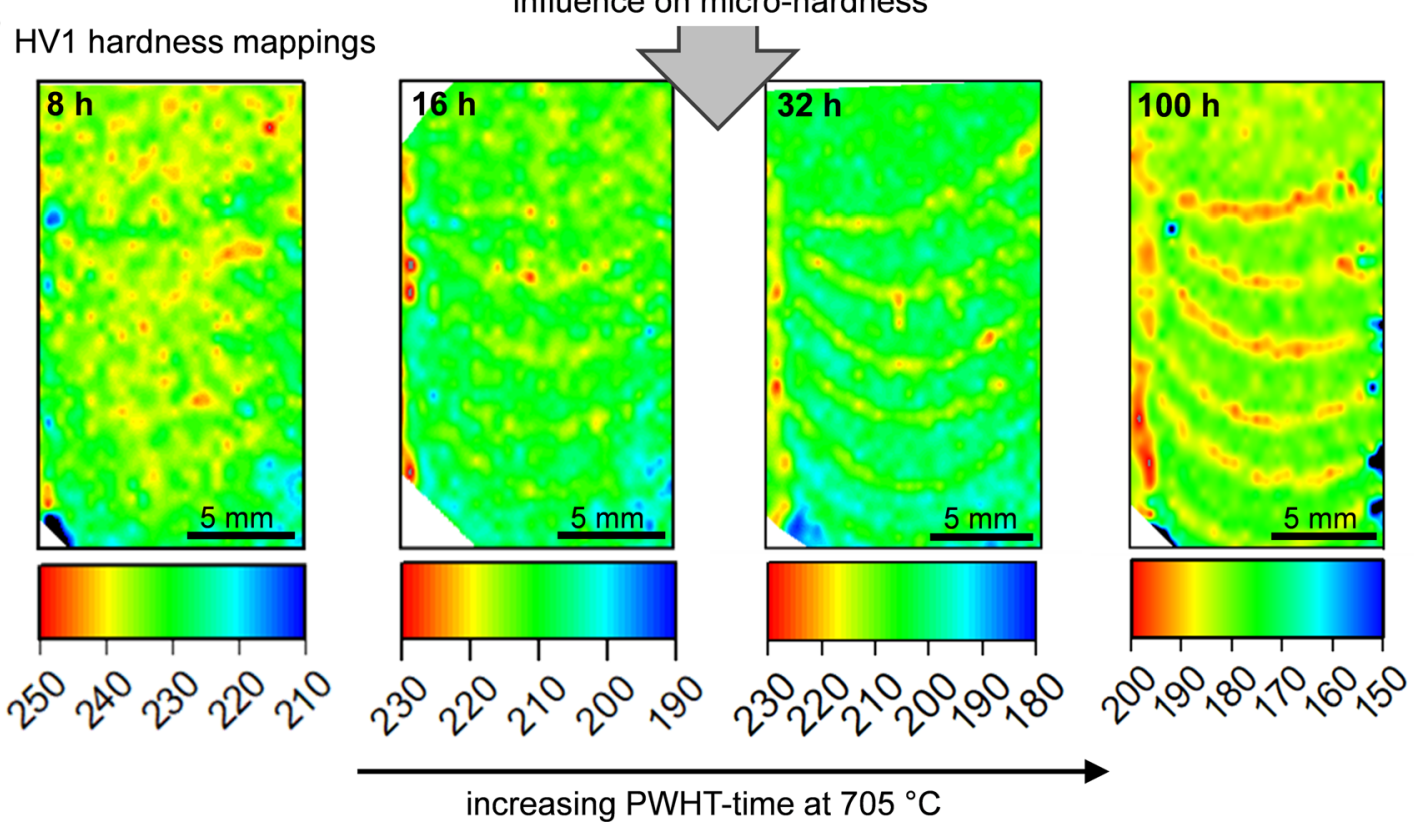

Figure 5 a BSE SEM image of a region within the last deposited weld bead of the specimen with a PWHT-time of $100 \mathrm{~h}$. b Carbide area fraction of the last deposited weld bead and the HAZ between the last and the subjacent weld bead for different PWHT-times and c the corresponding HV1 hardness mappings. 
an overview of the morphological changes of the prior austenite grain structure across the last deposited weld bead and the HAZ between the last and the subjacent weld bead of the specimen in the as-welded condition. Figure 6b, c displays more detailed EBSD scans taken at higher magnifications in both investigated regions of the same specimen. The reconstructed prior austenite grain boundaries are highlighted with black lines, respectively. The EBSD maps show that the prior austenite grains in the last deposited weld bead are large and elongated in the direction of solidification (Fig. 6b). On the contrary, the austenite grains within the subjacent HAZ are equiaxed and considerably smaller than those within the last deposited weld bead (Fig. 6c).
The weld metal specimen with a PWHT of $10 \mathrm{~h}$ at $705{ }^{\circ} \mathrm{C}$ showed a similar morphology of the prior austenite grain structure, not depicted here. Comparable to Fig. 6, the prior austenite grains are elongated and larger in the last deposited weld bead and equiaxed and smaller in the HAZ between the last and the subjacent weld bead.

Table 4 displays the mean bainite grain size in the last deposited weld bead and in the HAZ between the last and the subjacent weld bead of the specimen in the as-welded condition and after a PWHT-time of $10 \mathrm{~h}$ at $705{ }^{\circ} \mathrm{C}$, also determined via EBSD. For both sample conditions the bainite grain size in the last deposited weld bead is slightly larger than in the HAZ between the last and the subjacent weld bead. Furthermore, the grain size in the specimen with a



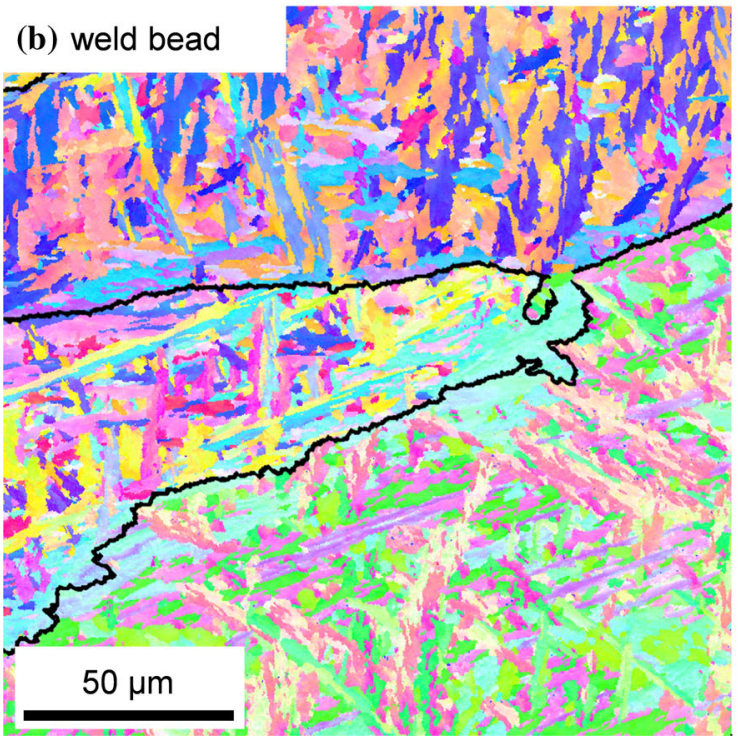

Figure 6 a EBSD scan providing an overview of the region in and close to the HAZ between the last deposited and the subjacent weld bead as well as EBSD scans at higher magnification from $\mathbf{b}$ an area within the last deposited weld bead and $\mathbf{c}$ an area within

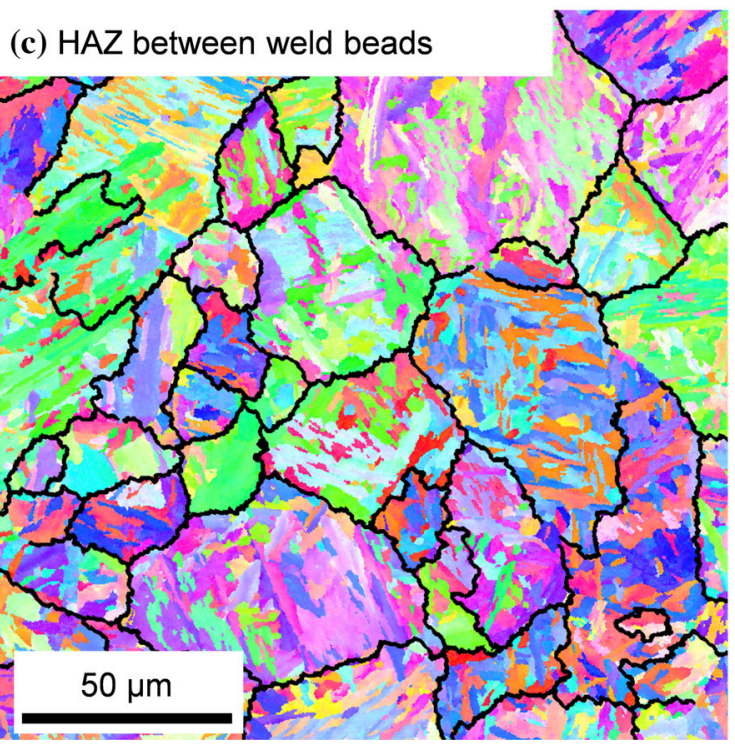

the subjacent HAZ. All EBSD maps were taken on the specimen in the as-welded condition and were superimposed with the calculated prior austenite grain boundaries. 
Table 4 Mean bainite grain size in the last deposited weld bead and in the HAZ between the last and the subjacent weld bead for two different PWHT conditions

\begin{tabular}{lll}
\hline Region & As-welded $(\mu \mathrm{m})$ & PWHT: $705^{\circ} \mathrm{C}-10 \mathrm{~h}(\mu \mathrm{m})$ \\
\hline Last deposited weld bead & 7.5 & 9.2 \\
HAZ between last and subjacent weld bead & 7.1 & 7.8 \\
\hline
\end{tabular}

PWHT-time of $10 \mathrm{~h}$ is higher than that in the aswelded condition for both investigated regions.

\section{High resolution investigation of the microstructure}

The dislocation structure as well as the distribution, size and shape of the precipitates in the as-welded condition and after different PWHT-times at $705{ }^{\circ} \mathrm{C}$ were investigated via STEM. Figure 7a shows the microstructure in the as-welded condition. The bainitic matrix exhibits a high density of severely tangled dislocations. No ordered structures such as dislocation nets or subgrain boundaries are visible. Figure $7 \mathrm{~b}-\mathrm{e}$ displays the microstructure of the multilayer weld metal heat treated for $8,16,32$ and $100 \mathrm{~h}$ at $705{ }^{\circ} \mathrm{C}$. After $8 \mathrm{~h}$ PWHT-time (Fig. 7b) the dislocation density is high, but reduced compared to the aswelded condition. Dislocation nets have already formed locally, though no subgrain boundaries are visible yet. The dislocations within the grains are still severely tangled and a high density of fine spherical shaped precipitates is present. These fine precipitates are mostly situated in the direct proximity of
Figure 7 STEM images of the multi-layer weld metals microstructure in a the aswelded condition and after varying PWHT-times of $\mathbf{b} 8 \mathrm{~h}$, c $16 \mathrm{~h}, \mathrm{~d} 32 \mathrm{~h}$ and $\mathrm{e} 100 \mathrm{~h}$ at $705{ }^{\circ} \mathrm{C}$.
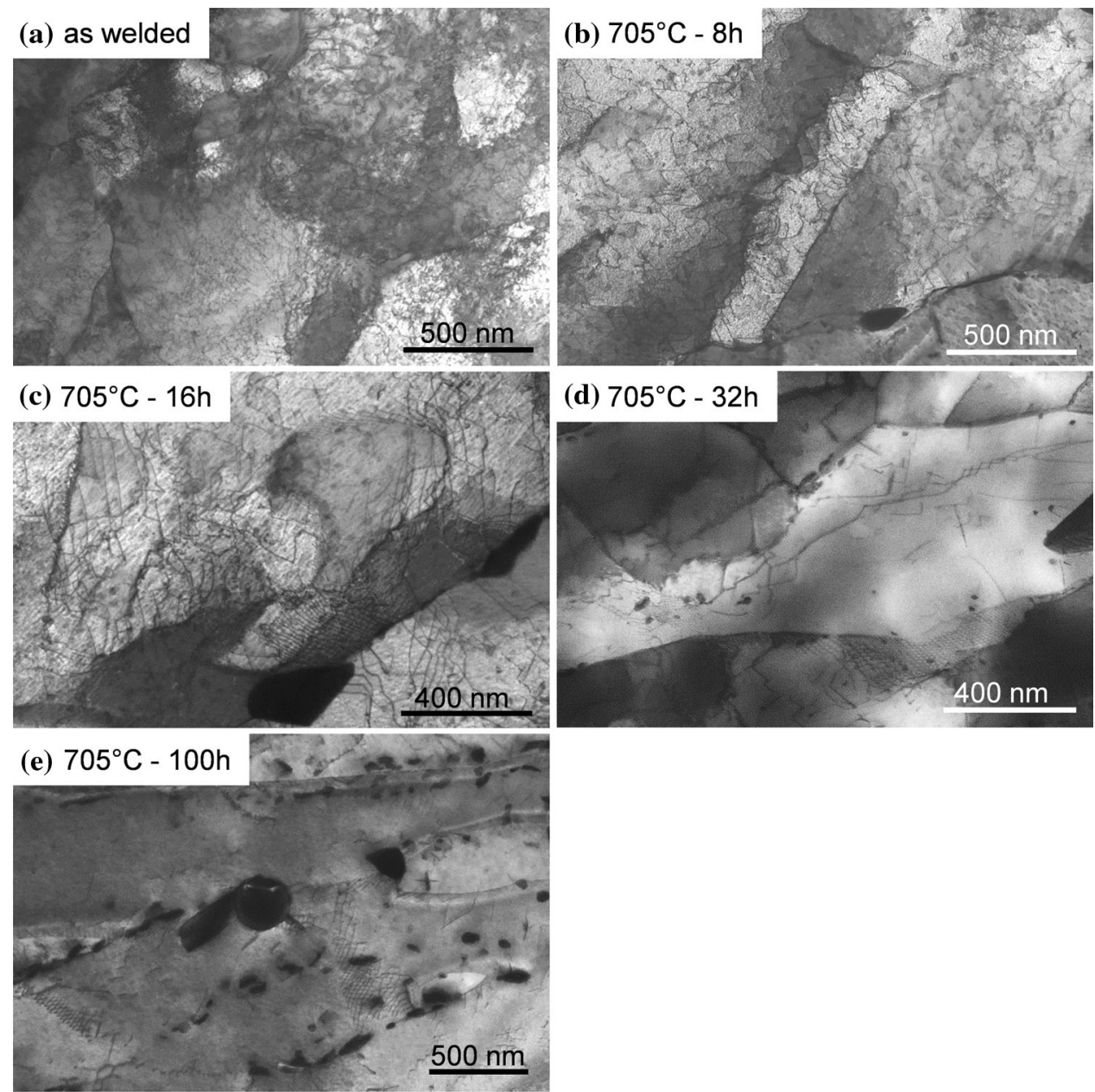
dislocations. After longer PWHT-times at $705^{\circ} \mathrm{C}$ the dislocation density is further reduced and the dislocations form more and more ordered arrangements such as dislocation nets or subgrain boundaries. Furthermore, after $16 \mathrm{~h}$ of PWHT (Fig. 7c) small oval and also rod-like shaped precipitates of up to $50 \mathrm{~nm}$ in length decorate the grain and subgrain boundaries. These precipitates along the boundaries are small, but larger than the fine precipitates within the grains and increase in number and size with longer duration of PWHT. The comparison of the STEM images of the microstructure after 16 and $32 \mathrm{~h}$ PWHT-time (Fig. 7c, d) reveals that with the growth of the oval and rodlike precipitates at the boundaries, the amount of the much finer spherical precipitates within the grains decreases significantly. Moreover, simultaneously with the dissolution of the fine spherical precipitates within the grains, the dislocation density is further decreased. In addition, after $32 \mathrm{~h}$ PWHT-time nearly no tangled dislocations are visible anymore. After $100 \mathrm{~h}$ of PWHT (Fig. 7e), the smaller oval and rodlike precipitates at the grain and subgrain boundaries are severely coarsened and exhibit lengths of about $100 \mathrm{~nm}$. Additionally, the fine precipitates within the grains have nearly disappeared completely. In comparison to the microstructure of the specimen with $32 \mathrm{~h}$ PWHT-time, the dislocation density after $100 \mathrm{~h}$ of PWHT is only slightly reduced. The reduction of the dislocation density is clearly more pronounced for the shorter PWHT-times. For longer PWHT-times than $32 \mathrm{~h}$, the dislocation density is already very low and primarily coarsening of the smaller precipitates seems to take place. In all post weld heat treated specimens, the grain boundaries are decorated with larger precipitates of maximum $500 \mathrm{~nm}$ in length. They exhibit various shapes from oval to rectangular to blocky or even spherical. In many cases there is an overlap of precipitates which makes it difficult to determine their exact shape and size. However, no significant changes regarding the appearance of these larger precipitates was detected in the specimens with increasing PWHT-time.

TKD was performed on carbon replicas of the weld metal sample with a PWHT-time of $100 \mathrm{~h}$. In this PWHT condition, the smaller precipitates at the grain and subgrain boundaries are severely coarsened and therefore easier to identify. Figure 8 shows the results of the TKD analysis of these coarsened oval and rodlike shaped precipitates. The extraction from the matrix via carbon replica method prevented overlapping of the Kikuchi patterns of the precipitates with the Kikuchi patterns of the matrix. Therefore, it was possible to unambiguously identify the crystal structure of the oval and rod-shaped precipitates as type MX. In Fig. 8 the TKD Kikuchi patterns of four MX precipitates and the patterns superimposed with the corresponding planes of the cubic MX crystal are shown. The carbides 2 to 4 , exhibit relatively similar orientations to the incident electron beam.

\section{Discussion}

\section{Correlation between PWHT-time, mechanical properties and microstructure}

The mechanical testing of the $2.25 \mathrm{Cr}-1 \mathrm{Mo}-0.25 \mathrm{~V}$ weld metal revealed that the impact energy and stress rupture time behave contrarily depending on the PWHT-time. To achieve a beneficial combination of toughness and creep resistance, the PWHT-time has to be long enough to ensure higher toughness one the one hand, but as short as possible to achieve a high resistance against creep deformation on the other hand. For a PWHT temperature of $705^{\circ} \mathrm{C}$, an annealing time of $16 \mathrm{~h}$ provides a good compromise of a well-balanced relation of impact energy and stress rupture time. In addition, strength and ductility are comparatively high after this duration of PWHT. Annealing times of $32 \mathrm{~h}$ and more lead to shorter stress rupture times but do not further enhance the weld metals impact toughness.

The changes in mechanical properties depending on the PWHT-time can be traced back to microstructural changes such as recovery processes of the dislocation structure and Ostwald ripening [20, 45] of fine MX carbonitrides. As soon as the equilibrium amount of $\mathrm{MX}$ carbonitrides is reached at a certain temperature, coarsening of the larger particles takes place at the expense of the smaller ones [46]. The STEM analysis revealed that an increasing PWHT-time at $705{ }^{\circ} \mathrm{C}$ causes a significant reduction of the dislocation density compared to the as-welded state. Furthermore, the dislocations rearrange to dislocation nets and in further consequence form subgrain boundaries. This is linked to the coarsening of fine MX carbonitrides with increasing time at $705{ }^{\circ} \mathrm{C}$. Due to the larger carbonitride size after longer PWHT-times, their ability to stabilize the subgrain 

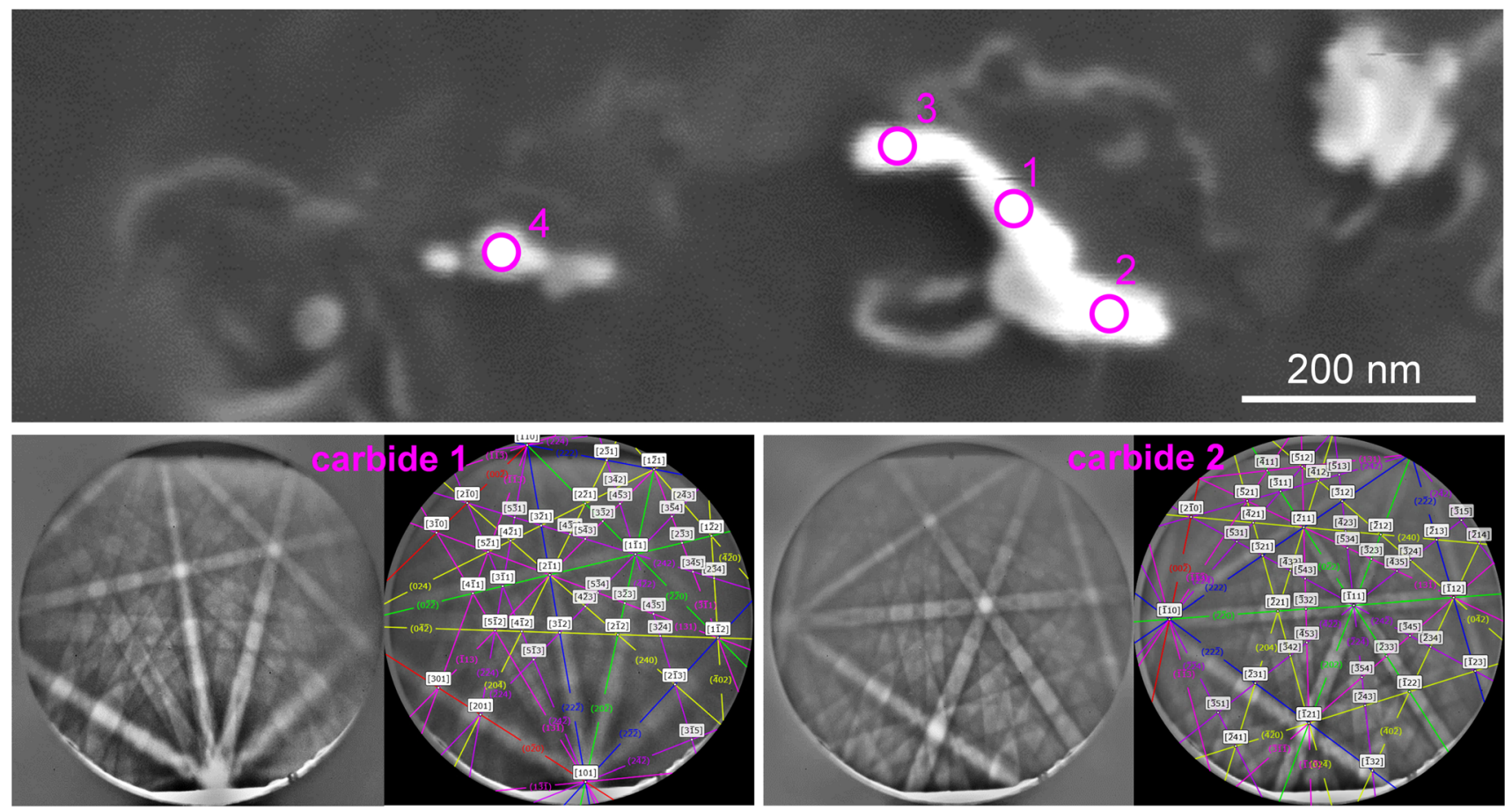

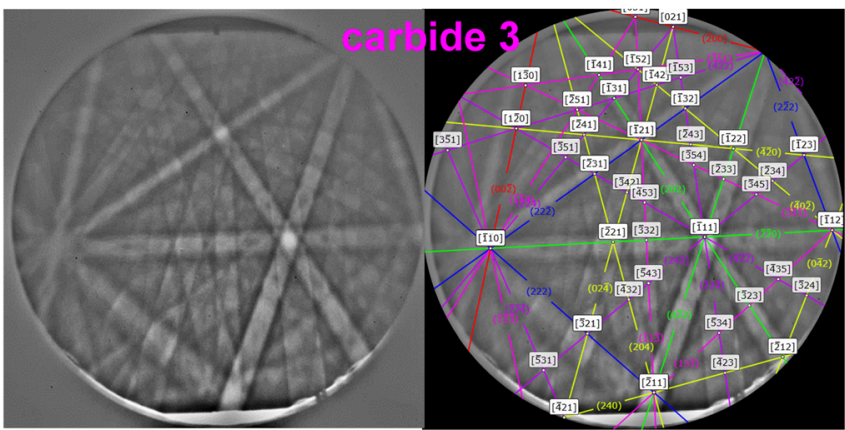

Figure 8 SEM image of small oval and rod-like shaped precipitates on a carbon replica of the specimen with a PWHTtime of $100 \mathrm{~h}$. The corresponding Kikuchi patterns of the four

microstructure is significantly reduced, as also observed in other CrMoV-steels [47-50]. While the MX carbonitrides effectively pin dislocations after 8 and $16 \mathrm{~h}$, they seem to lose their pinning force after longer PWHT-times. After prolonged PWHT-times, severe coarsening of the MX precipitates occurs and the remaining precipitates are mostly situated along grain and subgrain boundaries. Simultaneously, the smaller spherical MX carbonitrides within the grains nearly completely dissolve. The larger MX carbonitrides at the boundaries grow at the expense of the smaller ones within the grains. As these larger MX precipitates are not able to hinder the recovery process and the accompanying dissolution of dislocations effectively, the dislocation density is strongly



precipitates obtained by TKD and the superimposed solution for MX crystals are displayed below.

reduced with increasing PWHT-time. Furthermore, the coarsening leads to a higher inter-particle spacing of the MX carbonitrides. Thus, the Orowan stress is decreased and the dislocations can move more easily when load is applied, which manifests as a decrease in strength and stress rupture time as well as an increase in ductility.

\section{Factors influencing the weld metals hardness distribution}

The lower hardness of the HAZs in-between the weld beads in the as-welded condition and up to a PWHTtime of $8 \mathrm{~h}$ is expected to be caused by reheating to the austenitic phase field during multi-layer welding. This reaustenitization causes smaller equiaxed prior 
Figure 9 Schematic drawing of the microstructural changes in the last deposited weld bead and in the subjacent heataffected zone during PWHT at $705{ }^{\circ} \mathrm{C}$.



homogeneous hardness



HAZ are softer than weld beads

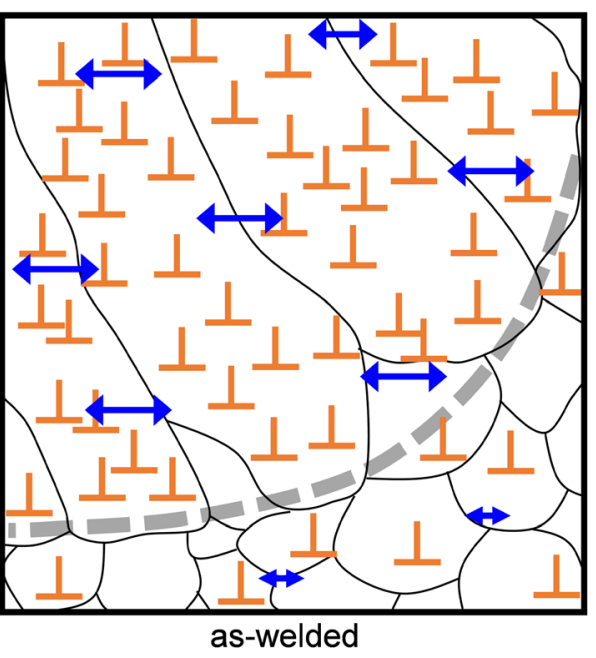

enhanced temper resistance of the HAZs

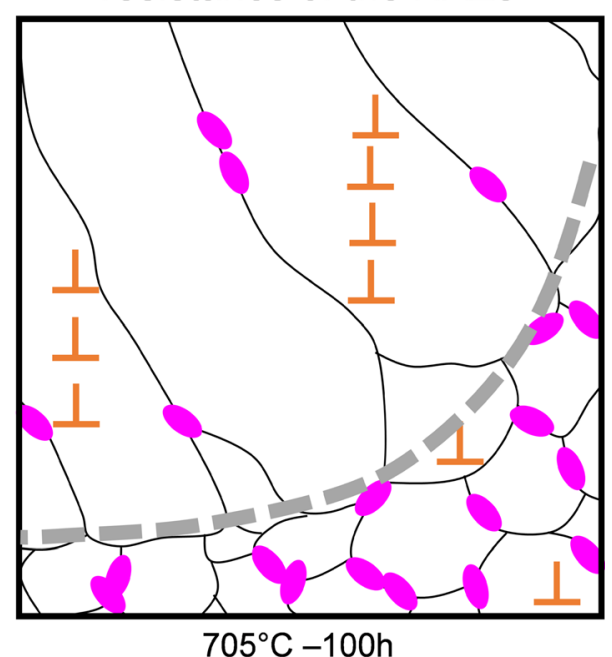

austenite grains and also a smaller bainite grain size compared to the regions within the weld beads, where the temperature increase by reheating during multi-layer welding was less pronounced. Moreover, the local reaustenitization reduces residual stresses from welding which leads to a lower hardness of the HAZs in-between the weld beads. Similar inhomogeneities in terms of microstructure and hardness over the multi-layer weld metals cross section are also described by Liu et al. for high-Cr CrMoV-steel in the as-welded condition [36].

After 8 and $10 \mathrm{~h}$ of PWHT, the weld metals hardness is nearly homogeneous. This is assumed to result from recovery processes of the microstructure. All regions within the multi-layer weld metal soften and the hardness of the weld beads assimilates with the hardness of the HAZs in-between. As the overall dislocation density is reduced with longer duration of PWHT, the local differences in hardness are minimized leading to a relatively homogeneous hardness.

In contrast, longer PWHT-times of $12 \mathrm{~h}$ and more again lead to a non-homogenous hardness of the weld metals cross section. The higher hardness of the HAZs in-between the weld beads correlates with a higher amount of larger carbides in these regions of 
the multi-layer weld metal. As only the larger carbide types which were visible at a magnification of 2500 in the SEM could be analysed, they were most likely $\mathrm{M}_{23} \mathrm{C}_{6}$ and $\mathrm{M}_{7} \mathrm{C}_{3}$ carbides [31, 51-54]. The carbide area fraction analysis revealed that the amount of the larger carbides is higher in the HAZ between the last and the subjacent weld bead than within the last deposited weld bead and that this difference in carbide area fraction increases with longer PWHT-time. This increasing difference in carbide area fraction is in consistence with the higher hardness of the HAZs in the multi-layer weld metal compared to the weld beads. Like the difference in carbide area fraction, also the difference in hardness becomes more pronounced with increasing PWHTtime. However, the higher hardness of the HAZs within the multi-layer weld metal is not a secondary hardening effect indeed. The HAZs exhibit an enhanced temper resistance and soften less than the regions within the weld beads. The overall hardness of the weld metal still decreases with longer PWHTtime due to the recovery of the microstructure and consequently due to a reduction in dislocation density. Figure 9 provides a schematic overview aiming to visualize the discussed changes of the $2.25 \mathrm{Cr}-$ $1 \mathrm{Mo}-0.25 \mathrm{~V}$ weld metals microstructure and the correlation with its micro-hardness distribution with increasing duration of PWHT.

Except from the enhanced temper resistance of the HAZs in-between the weld beads, also a gradient in hardness from the top to the bottom weld layer appears in all PWHT conditions. This hardness gradient is referred to the tempering treatment by the overlying weld beads in the course of multi-layer welding. The weld beads in the lower layers are reheated multiple more times than the weld beads in the upper layers of the weld metal.

Finally, it has to be emphasised that the enhanced temper resistance of the HAZs in-between the weld beads of the $2.25 \mathrm{Cr}-1 \mathrm{Mo}-0.25 \mathrm{~V}$ multi-layer weld metal is most probably caused by multiple influencing factors. These include local variations of the temperature profile during multi-layer welding, a varying prior austenite and bainite grain size, segregations of $\mathrm{C}$ and carbide forming elements as well as local differences in carbide area fraction.

\section{Conclusions}

The present study sheds light on the impact of PWHT-time at $705{ }^{\circ} \mathrm{C}$ on the microstructure and mechanical properties of $2.25 \mathrm{Cr}-1 \mathrm{Mo}-0.25 \mathrm{~V}$ multilayer weld metal fabricated by SAW. Based on the results from mechanical testing and the high resolution investigation of the dislocation structure and precipitates by means of STEM and TKD, the following conclusions can be drawn:

- Toughness and creep resistance of the $2.25 \mathrm{Cr}$ $1 \mathrm{Mo}-0.25 \mathrm{~V}$ multi-layer weld metal behave contrarily: A longer PWHT-time at $705{ }^{\circ} \mathrm{C}$ leads to an increase of the impact energy and a reduction of the stress rupture time.

- The loss of stress rupture time with longer duration of PWHT is caused by recovery processes of the dislocation structure by enforced severe coarsening of fine $\mathrm{MX}$ carbonitrides.

- A PWHT-time of $16 \mathrm{~h}$ at $705{ }^{\circ} \mathrm{C}$ leads to a beneficial combination of Charpy impact energy and stress rupture time.

- A PWHT of $12 \mathrm{~h}$ and more causes an enhanced temper resistance of the HAZs in-between the weld beads, which becomes more pronounced with increasing PWHT-time.

- The enhanced temper resistance of the HAZs inbetween the weld beads of the multi-layer weld metal is assumed to be linked to multiple influencing factors. These influencing factors include:

- A smaller prior austenite and slightly smaller bainite grain size in the HAZs in-between the weld beads than in the regions within the weld beads caused by the reaustenitization in the course of multi-layer welding.

- A higher amount of larger carbides in the HAZs in-between the weld beads compared to the regions within the weld beads.

- An increasing difference of the amount of larger carbides between the HAZs in-between the weld beads and the regions within the weld beads with longer duration of PWHT. 


\section{Acknowledgements}

Funding of the Austrian BMK (846933) in the framework of the program "Production of the future" and the "BMK Professorship for Industry" is gratefully acknowledged.

\section{Funding}

Open access funding provided by Montanuniversität Leoben.

\section{Declarations}

Conflict of interest The authors declare that they have no conflict of interest.

Open Access This article is licensed under a Creative Commons Attribution 4.0 International License, which permits use, sharing, adaptation, distribution and reproduction in any medium or format, as long as you give appropriate credit to the original author(s) and the source, provide a link to the Creative Commons licence, and indicate if changes were made. The images or other third party material in this article are included in the article's Creative Commons licence, unless indicated otherwise in a credit line to the material. If material is not included in the article's Creative Commons licence and your intended use is not permitted by statutory regulation or exceeds the permitted use, you will need to obtain permission directly from the copyright holder. To view a copy of this licence, visit http://creativecommons.org/licen ses/by/4.0/.

\section{References}

[1] Hucińska J (2003) Advanced vanadium modified steels for high pressure hydrogen reactors. Adv Mater Sci 4(2):21-27

[2] Detemple I, Hanus F, Luxenburger G (1999) Advanced steels for hydrogen reactors. Hydrocarb Eng 4:1-8

[3] Pereira PAS, Franco CSG, Guerra Filho JLM, dos Santos DS (2015) Hydrogen effects on the microstructure of a $2.25 \mathrm{Cr}-$ $1 \mathrm{Mo}-0.25 \mathrm{~V}$ steel welded joint. Int J Hydrogen Energy 40:17136-17143. https://doi.org/10.1016/j.ijhydene.2015.07 .095

[4] Ichikawa K, Horii Y, Sueda A, Kobayashi J (1995) Thoughness and creep strength of modified $2.25 \mathrm{Cr}-1 \mathrm{Mo}$ steel weld metal. Weld J-Incl Weld Res Suppl 74(7):230-238
[5] Antalffy LP, Chaku PN, Canonico DA, Pfeifer JA, Alcorn DG (2002) The potential for using high chromium ferritic alloys for hydroprocessing reactors. Int J Press Vessels Pip. https://doi.org/10.1016/S0308-0161(02)00090-X

[6] Chovet C, Schmitt J-P (2011) Additional recommendations for welding $\mathrm{Cr}-\mathrm{Mo}-\mathrm{V}$ steels for petrochemical applications. Weld World. https://doi.org/10.1007/BF03321540

[7] Cheruvu NS (1989) Degradation of mechanical properties of $\mathrm{Cr}-\mathrm{Mo}-\mathrm{V}$ and $2.25 \mathrm{Cr}-1 \mathrm{Mo}$ steel components after longterm service at elevated temperatures. Metall Mat Trans A 20:87-97. https://doi.org/10.1007/BF02647496

[8] Takauchi H, Nako H, Nakanishi T (2017) Welding consumables for $2.25 \mathrm{Cr}-1 \mathrm{Mo}-\mathrm{V}$ refining reactors. In: Proceeding of the ASME 2017 pressure vessels and piping conference, Hawaii, USA

[9] Mohyla P, Foldyna V (2009) Improvement of reliability and creep resistance in advanced low-alloy steels. Mater Sci Eng A. https://doi.org/10.1016/j.msea.2008.05.056

[10] Rösler J, Harders H, Bäker M (2012) Mechanisches Verhalten der Werkstoffe. Springer Fachmedien Wiesbaden, Wiesbaden

[11] Bürgel R, Jürgen Maier H, Niendorf T (2011) Handbuch Hochtemperatur- Werkstofftechnik: Grundlagen, Werkstoffbeanspruchungen, Hochtemperaturlegierungen und beschichtungen; mit 66 Tab, 4th edn. Praxis. Vieweg+Teubner Verlag/Springer Fachmedien Wiesbaden GmbH Wiesbaden, Wiesbaden

[12] Abe F (2016) Progress in creep-resistant steels for high efficiency coal-fired power plants. J Pressure Vessel Technol. https://doi.org/10.1115/1.4032372

[13] Abe F (2004) Bainitic and martensitic creep-resistant steels. Curr Opin Solid State Mater Sci. https://doi.org/10.1016/j.c ossms.2004.12.001

[14] Sklenicka V (2003) Long-term creep behavior of 9-12\% $\mathrm{Cr}$ power plant steels. Mater Charact. https://doi.org/10.1016/j. matchar.2003.09.012

[15] Abe F (2001) Creep rates and strengthening mechanisms in tungsten-strengthened $9 \mathrm{Cr}$ steels. Mater Sci Eng, A. https:// doi.org/10.1016/S0921-5093(00)02002-5

[16] Fu RD, Wang TS, Zhou WH, Zhang WH, Zhang FC (2007) Characterization of precipitates in a $2.25 \mathrm{Cr}-1 \mathrm{Mo}-0.25 \mathrm{~V}$ steel for large-scale cast-forged products. Mater Charact 56:968-973. https://doi.org/10.1016/j.matchar.2006.10.002

[17] Jäniche W, Dahl W, Klärner H, Pitsch W, Schauwinhold D, Schlüter W and Schmitz H (1985) Werkstoffkunde stahl: band 2: Anwendung. Springer, Berlin

[18] Masuyama F (2001) Advances in physical metallurgy and processing of steels. History of power plants and progress in heat resistant steels. ISIJ International. https://doi.org/10.23 55/isijinternational.41.612 
[19] Paddea S, Masuyama F, Shibli A (2014) T23 and T24 - new generation low alloyed steels, In: Coal power plant materials and life assessment, Woodhead Publishing, pp 87-106

[20] Maruyama K, Sawada K, Koike J-I (2001) Advances in physical metallurgy and processing of steels. Strengthening mechanisms of creep resistant tempered martensitic steel. ISIJ Int https://doi.org/10.2355/isijinternational.41.641

[21] Nabarro FRN, de Villiers HL (1995) The physics of creep: creep and creep-resistant alloys. Taylor \& Francis, London

[22] Abe F, Viswanathan R, Kern T-U (2008) Creep-resistant steels. Woodhead Publishing in materials no. 49. Woodhead Publishing Limited, Cambridge, England

[23] API Recommended Practice 934-A (2008) Materials and fabrication of $21 / 4 \mathrm{CR}-1 \mathrm{Mo}, 21 / 4 \mathrm{Cr}-1 \mathrm{Mo}-1 / 4 \mathrm{~V}, 3 \mathrm{Cr}-$ $1 \mathrm{Mo}$ and $3 \mathrm{Cr}-1 \mathrm{Mo}-1 / 4 \mathrm{~V}$ steel heavy wall pressure vessels for high-temperature, high-pressure hydrogen service, 2nd edn. API Publishing Services

[24] Chauvy C, Pillot S (2009) Prevention of weld metal reheat cracking during $\mathrm{CrMoV}$ heavy reactors fabrication. In: Proceeding of the ASME 2009 pressure vessels and piping conference, Prague, Czech Republic

[25] Schönmaier H, Krein R, Schmitz-Niederau M, Schnitzer R (2021) Influence of the heat input on the dendritic solidification structure and the mechanical properties of $2.25 \mathrm{Cr}-$ $1 \mathrm{Mo}-0.25 \mathrm{~V}$ submerged-arc weld metal. J Mater Eng Perform 30:7138-7151. https://doi.org/10.1007/s11665-021-05 922-x

[26] Clerge M, Boucher C, Pillot S, Balladon P, Bourges PH, Bertoni A (2005) Optimisation of intermediate heat treatments and stress relief of CrMoV steels. Weld Int. https://doi. org/10.1533/wint.2005.3495

[27] Dong P, Song S, Zhang J (2014) Analysis of residual stress relief mechanisms in post-weld heat treatment. Int $\mathrm{J}$ Press Vessels Pip. https://doi.org/10.1016/j.ijpvp.2014.06.002

[28] Samuel EI, Choudhary BK, Rao KBS (2007) Influence of post-weld heat treatment on tensile properties of modified 9Cr-1Mo ferritic steel base metal. Mater Sci Technol. https:// doi.org/10.1179/174328407X161295

[29] DuPont JN, Siefert JA, Shingledecker JP (2017) Microstructural evolution and mechanical properties of Grades 23 and 24 creep strength enhanced ferritic steels. Int Mater Rev. https://doi.org/10.1080/09506608.2016.1207008

[30] Jiang Z, Wang P, Li D, Li Y (2017) The evolutions of microstructure and mechanical properties of $2.25 \mathrm{Cr}-1 \mathrm{Mo}-$ $0.25 \mathrm{~V}$ steel with different initial microstructures during tempering. Mater Sci Eng A 699:165-175. https://doi.org/ 10.1016/j.msea.2017.05.095

[31] Klueh RL, Swindeman RW (1986) The microstructure and mechanical properties of a modified $2.25 \mathrm{Cr}-1 \mathrm{Mo}$ steel.
Metall Mat Trans A 17:1027-1034. https://doi.org/10.1007/ BF02661268

[32] Luxenburger G, Detemple I, Hanus F (2002) Comparison of CrMoV steel grades with the enhanced CrMo-steel $12 \mathrm{CrMo}$ 9-10 for the use in petrochemical reactors. Rev Met Paris. https://doi.org/10.1051/metal:2002147

[33] Tipler HR, Taylor LH, Thomas GB, Williamson J, Branch GD, Hopkins BE (1975) Effect of heattreatment variations on strength and ductility of $\mathrm{Cr}-\mathrm{Mo}-\mathrm{V}$ steels during creep at $550^{\circ} \mathrm{C}$. Metals Technology. https://doi.org/10.1179/ 030716975803277609

[34] Yang B, Xuan F-Z (2019) Nonhomogeneous microstructure related creep damage of the $\mathrm{CrMoV}$ multi-pass weld metal. Mater Sci Eng, A. https://doi.org/10.1016/j.msea.2019. 138122

[35] Yang B, Xuan F-Z, Liu X-P (2017) Heterogeneous creep behavior of a CrMoV multi-pass weld metal. Mater Sci Eng, A. https://doi.org/10.1016/j.msea.2017.02.084

[36] Liu W, Lu F, Wei Y, Ding Y, Wang P, Tang X (2016) Special zone in multi-layer and multi-pass welded metal and its role in the creep behavior of 9Cr 1Mo welded joint. Mater Des. https://doi.org/10.1016/j.matdes.2016.06.102

[37] Deutsches Institut für Normung e. V. (2019) Zerstörende Prüfung von Schweißverbindungen an metallischen Werkstoffen: Längszugversuch an Schweißgut in Schmelzschweißverbindungen (ISO 5178:2019)

[38] Deutsches Institut für Normung e. V. (2017) Metallische Werkstoffe-Kerbschlagbiegeversuch nach Charpy: teil 1: prüfverfahren (ISO 148-1:2016)

[39] Deutsches Institut für Normung e. V. (2020) Zerstörende Prüfung von Schweißverbindungen an metallischen Werkstoffen-Kerbschlagbiegeversuch: Probenlage, Kerbrichtung und Beurteilung (ISO 9016:2020)

[40] American Society of Mechanical Engineers (2017) ASME boiler and pressure vessel code: division 2 alternative rules, New York

[41] American Society for Testing and Materials (2018) Test methods for conducting creep, creep-rupture, and stressrupture tests of metallic materials (E139-11), West Conshohocken, PA. ASTM International

[42] Cayron C (2007) ARPGE: a computer program to automatically reconstruct the parent grains from electron backscatter diffraction data. J Appl Crystallogr. https://doi. org/10.1107/S0021889807048777

[43] Bhattacharya A, Parish CM, Henry J, Katoh Y (2019) High throughput crystal structure and composition mapping of crystalline nanoprecipitates in alloys by transmission Kikuchi diffraction and analytical electron microscopy. Ultramicroscopy. https://doi.org/10.1016/j.ultramic.2019.03.015 
[44] Sneddon GC, Trimby PW, Cairney JM (2016) Transmission Kikuchi diffraction in a scanning electron microscope: a review. Mater Sci Eng R Rep. https://doi.org/10.1016/j.mser. 2016.10.001

[45] Voorhees PW (1985) The theory of Ostwald ripening. J Stat Phys. https://doi.org/10.1007/BF01017860

[46] Taneike M, Kondo M, Morimoto T (2001) Accelerated coarsening of MX Carbonitrides in $12 \% \mathrm{Cr}$ steels during creep deformation. ISIJ Int. https://doi.org/10.2355/isijinter national.41.Suppl_S111

[47] Zieliński A, Golański G, Sroka M (2017) Influence of longterm ageing on the microstructure and mechanical properties of T24 steel. Mater Sci Eng A. https://doi.org/10.1016/j.ms ea.2016.11.087

[48] Golański G, Zielińska-Lipiec A, Mroziński S, Kolan C (2015) Microstructural evolution of aged heat-resistant cast steel following strain controlled fatigue. Mater Sci Eng, A. https://doi.org/10.1016/j.msea.2014.12.120

[49] Sawada K, Kubo K, Abe F (2003) Contribution of coarsening of MX carbonitrides to creep strength degradation in high chromium ferritic steel. Mater Sci Technol. https://doi. org/10.1179/026708303225010687

[50] Sawada K, Kubo K, Abe F (2001) Creep behavior and stability of MX precipitates at high temperature in $9 \mathrm{Cr}-0.5 \mathrm{Mo}-$
1.8W-VNb steel. Mater Sci Eng A 319-321:784-787. https:// doi.org/10.1016/S0921-5093(01)00973-X

[51] Yongtao Z, Haibo H, Lede M, Hanqian Z, Jinfu L (2009) Quantitative carbide analysis using the Rietveld method for $2.25 \mathrm{Cr}-1 \mathrm{Mo}-0.25 \mathrm{~V}$ steel. Mater Charact 60:953-956. https://doi.org/10.1016/j.matchar.2009.03.009

[52] Yongtao Z, Lede M, Xiaojun W, Hanqian Z, Jinfu L (2009) Evolution behavior of carbides in $2.25 \mathrm{Cr}-1 \mathrm{Mo}-0.25 \mathrm{~V}$. Steel Mater Trans 50:2507-2511. https://doi.org/10.2320/matertra ns.M2009172

[53] Tao P, Zhang C, Yang Z-G, Takeda H (2010) Evolution and coarsening of carbides in $2.25 \mathrm{Cr}-1 \mathrm{Mo}$ steel weld metal during high temperature tempering. J Iron Steel Res Int 17:74-78. https://doi.org/10.1016/S1006-706X(10)60103-3

[54] Výrostková A, Kroupa A, Janovec J, Svoboda M (1998) Carbide reactions and phase equilibria in low alloy $\mathrm{Cr}-\mathrm{Mo}-$ V steels tempered at 773-993 K. Part I: Experimental measurements. Acta Materialia. https://doi.org/10.1016/S13 59-6454(97)00238-3

Publisher's Note Springer Nature remains neutral with regard to jurisdictional claims in published maps and institutional affiliations. 